\title{
The Market and Investors Reactions to Mariana's and Brumadinho's Environmental Disasters: Sentimental or Rational Decisions?
}

\author{
Moacir Sancovschi ${ }^{1}$, Adolfo Henrique Coutinho e Silva ${ }^{1} \&$ José Paulo Cosenza $^{2}$ \\ ${ }^{1}$ Accounting Departament, Federal University of Rio de Janeiro, Rio de Janeiro, Brazil \\ ${ }^{2}$ Accounting Departament, Fluminense Federal University, Niterói, Brazil \\ Correspondence: Adolfo Henrique Coutinho e Silva, Faculty of Administration and Accounting, Federal \\ University of Rio de Janeiro, Av. Pasteur, 250 - CEP: 22.290-240 - Praia Vermelha, Urca - Rio de Janeiro/RJ, \\ Brazil.
}

Received: November 3, 2021

Accepted: December 29, 2021

Online Published: January 8, 2022

doi:10.5539/jms.v12n1p37

URL: https://doi.org/10.5539/jms.v12n1p37

\begin{abstract}
This research carried out event studies to analyze the reactions of the market and investors in Vale S.A. to the collapses of the Mariana and Brumadinho dams. It also assessed the extent to which the causes attributed to the market reactions to major disasters in previous research has helped to explain the reactions of the market and investors to the collapses of these dams. The analyses have shown that, in the case of the Fundão dam, there was a relevant reduction in the abnormal cumulative returns of common stocks and ADRs at the end of the eleven days of the collapse, despite the fact that the daily abnormal returns were not statistically significant. However, the abnormal trading volumes of these securities in the eleven days after the dam failure were generally negative and all statistically significant. In contrast, concerning the collapse of the Brumadinho dam, the abnormal returns on common stocks and ADRs were negative, relevant, and statistically significant, and, after the eleven days, the losses were considerable. The abnormal trading volumes of the securities were all positive and statistically significant, but the reactions of ADR investors were more intense than those of investors in common stocks. Examining the causal attributions made previously, there are indications that the market and investor reactions to the failures of the two dams were probably derived from the expectation that Vale and the other companies involved would incur severe losses and high contracting costs in political processes that would follow to the disasters, and from the difficulty the investors have had to assess the magnitude of these losses and costs.
\end{abstract}

Keywords: corporate social responsibility, event study analysis, market and investors reaction, environmental disasters, tailings dam collapse

\section{Introduction}

On November 5, 2015, the Fundão dam, located in the Germano Complex in the city of Mariana in the State of Minas Gerais, Brazil, collapsed. It was owned by Samarco, a joint venture equally controlled by Vale S.A. and BHP Billiton Brazil Ltd. According to Fundação Renova (2017) (Note 1), the collapse caused the leakage of approximately 32.6 million $\mathrm{m}^{3}$ of iron ore tailings and Ragazzi and Rocha (2019) reported that the actual leak that impacted the environment was 43.7 million $\mathrm{m}^{3}$ of tailings, affecting 39 municipalities in Minas Gerais and Espírito Santo States. "The Fundão dam failure resulted in 19 fatalities, the displacement of more than 220 families, pollution and disruption of $670 \mathrm{~km}$ of river and a large oceanic area, among several other serious short- and long-term consequences" (Sánchez et al., 2018, p. 1).

Four years after The Fundão tragedy, on January 25, 2019, the tailings of Dam 1 on the Córrego do Feijão, located in the city of Brumadinho in the state of Minas Gerais, Brazil, and owned by Vale S.A., collapsed. Ragazzi and Rocha (2019) reported that the 10.5 million $\mathrm{m}^{3}$ of tailings reached the administrative area of the mine downstream of the dam and parts of the communities of Córrego do Feijão and Parque da Cachoeira on the outskirts of Brumadinho, reaching the Paraopeba River. The accident death toll was 270 deaths in addition to causing extensive and severe material, social, and environmental damage to the region.

Environmental accidents like these are not as rare as one might think, unfortunately. Espindola and Guimarães (2019) mention two similar cases. The first was the collapse in July 1985 of the Stava dam, belonging to Prealpi Mineraria, located in Tesero in the Trento region of Italy, which resulted in the death of 268 people and damaged 
an important tourist center; and the second case was the failure of Imperial Metals Corporation's Mount Polley Dam in British Columbia, a province of Canada, in August 2014.

As Simeoni, Tosatti, Luca and Longo (2017), Marshall (2018), and Ragazzi and Rocha (2019) described, these four accidents had very similar circumstances. Installations belonged to large companies, dams built using the upstream method, neglect with maintenance and safety equipment, and inattention to signs of impending problems.

Ragazzi and Rocha $(2019$, pp. 23, 24) state that the upstream method is "cheaper and less safe because the construction uses the waste disposed inside the reservoir, and the engineering of its inclination makes it less stable". Simeoni et al. (2017) comment that mining companies choose the most economical methods of construction of tailings dams, to the detriment of stability, because the tailings from the ore processing are inevitable, generate costs and do not contribute to the companies' revenues. According to Mintzberg (1982), this is a reductionist conception that equates efficiency with the reduction of economic costs, forgetting that there are relevant social costs that are treated as externalities or neighborhood effects. Davies and Martin (2009) provide weak evidence that this conception has prevailed in the case of dam management in mining companies. They compared 143 incidents with tailings dams that occurred in the period from December 1968 to August 2009 with the prices of the main mining commodities to conclude that "there seems to be some validity for the hypothesis that the increase in the frequency of incidents can be expected in a short period of time after a vigorous growth cycle in the mining industry" (abstract), a time when there is a large accumulation of tailings.

This article has three objectives. The first is to show that the reaction of the capital market to the collapses of Fundão and of Córrego do Feijão dams, expressed in the returns of ADRs and Vale S.A. common stocks, given the particularities of each case, was similar to the reactions observed in the several studies on the financial repercussions of major disasters in the capital markets.

Beaver (1968) and Baker and Wurgler (2007) consider that there is a difference between market reactions and investors' reactions. For them, the reactions or sentiment of investors is measured by the volume of securities traded that express the sum of the decisions of investors, and not by the behavior of the stock returns.

The following literature review, although not exhaustive, could not identify studies that had examined the reaction of investors to major accidents. Therefore, the second objective of this research is to document the reaction of investors expressed in the trading volume of ADR's and Vale S.A. common stocks in the eleven days following the collapses of the Fundão and of Córrego do Feijão dams.

Generally, studies of the impacts of major accidents on the capital markets make assumptions about likely causes for these impacts. The third objective of this research is to verify the extent to which the causes suggested in previous research help to explain the reactions of the market and of the investors in Vale's ADRs and common stocks to the rupture of the Fundão and Córrego do Feijão dams.

There are three main contributions of this research. First, it corroborates the results of several studies that have documented the market's reactions to major disasters that caused environmental damage and deaths, indicating that these results are, to a large extent, generalizable.

Second, it examines investors' reactions to major catastrophes, showing that the market and investors may react differently to the same stimulus, as stated by Beaver (1968). The results obtained in this research show that this divergence occurred in the case of the failure of the Fundão dam in Mariana. In this paper, we also provided additional evidence to Corporate Social Responsibility (CSR) literature by analyzing the investors and the market reaction to an extreme environmental disaster in a developing country. Besides, our empirical analysis relying on an event study to examine the effects of an important social and environmental disaster on the stock market seems effective for forward-looking evaluations of investors' behaviors regarding social and environmental issues concerns.

Third, the present research dedicates a section to the presentation of conjectures on the possible causes of the market and investors' reactions to the two accidents that, despite being similar, had some distinctive characteristics. In addition, we raised some practical considerations for the managers of mining companies who may face fortuitous accidents of large proportions, even when they have made their best efforts to prevent them from happening.

This paper is organized as follows: After this introduction, section 2 presents the literature review. Section 3 describes the research method applied. Section 4 shows the analysis of abnormal returns, cumulative abnormal returns, and abnormal trading volumes for Vale's common stocks and ADRs in the eleven days that followed the Mariana and Brumadinho disasters and speculates about the possible reasons for the reactions observed. Finally, 
section 5 ends the paper listing the conclusions reached and making the final comments.

\section{Literature Review}

Beaver (1968) stated that in order to assess the relevance of an event to the market, one must study the behavior of stock returns by the time of the event's disclosure because they express the expectations of the market as a whole. However, to assess the relevance of an event to investors, he has recommended that the behavior of the trading volume of stocks be examined when the event becomes officially known because the trading volume is determined by the sum of individual investors' reactions or, as Baker and Wurgler (2007) propose, the volume of stock traded is an indicator of investor sentiment. Bamber and Cheon (1995), Barron (1995), and Bamber, Barron, and Stober (1999) gathered evidence that supports these statements in the case of the disclosure of companies' profits. Therefore, in this research, we examined, separately, the reactions of the market and the investors to the collapses of the Mariana and Brumadinho dams.

Previous event studies about severe accidents have examined the stock market reactions to aviation disasters (Kaplanski \& Levy, 2010; Ho, Qiu, \& Tang, 2013), chemical disasters (Capelle-Blancard \& Laguna, 2010), industrial accidents (Wang, Qiu, \& Kong, 2011), environmental disasters in the oil industry (Katsikides, Markoulis, \& Papaminas, 2016), and nuclear catastrophes (Fersltl, Utz, \& Wimmer, 2012). In general, the previous studies show that even though the market reacts negatively to these accidents, the size and persistence of the reaction vary substantially from case to case. None of these studies looked at how investors reacted.

Kaplanski and Levy (2010) observed that the abnormal returns of the North American stock market reduced significantly on the first day after major aviation accidents that occurred in the period 1950-2007. These reductions, however, were partially reversed two days later, and, after ten days, returns went back to the same levels they were at before the accidents. In financial terms, these reductions caused average losses to the market of more than $\$ 60$ billion per accident, well above the average losses of $\$ 1$ billion per accident incurred by aviation companies.

Because they made no sense, these reactions were attributed by Kaplansky and Levy (2010) to investor sentiments, defined by Baker and Wurgler $(2007$, p. 129) as a "belief about future cash flows and investment risks that are not justified by the facts at hand". To justify this interpretation, Kaplansky and Levy (2010) showed that the reduction in share prices was accompanied by an increase in implied options volatility, measured by the VIX and VXO volatility indexes versions of the Fear Index, proposed by Baker and Wurgler (2007) as indicators of investors' sentiment. They also showed that the effects of accidents were more pronounced on the stocks of smaller companies, on the most volatile stocks, and on the stocks of companies of the most unstable industries whose returns are more sensitive to investor sentiments, as predicted by Baker and Wurgler (2007).

Considering that aviation accidents are emotionally reported in the media, and that these events have the potential to sensitize people, Kaplanski and Levy (2010) simply assumed that the feelings that stimulated investors' irrational responses were fear, anxiety, and mood swings.

As a counterpoint to the results and arguments of Kaplanski and Levy (2010), it is interesting to mention that Jones and Rubin (2001) observed that accidents involving 98 energy and oil companies in the 1970-1992 period, which did not harm the quality of their products and services, nor their reputations with suppliers and employees, did not have a significant negative impact on the companies' market value, despite having affected their social reputations. These results, according to them, support the hypothesis that the market's reactions to accidents are not driven by sentiments such as mood, fear, and anxiety, or by the desire of investors to punish companies that have caused damage to third parties.

Ho et al. (2013) compared the impacts aircraft accidents have had on the market value of North American airlines whose planes crashed with those of airlines that were not involved in accidents in the 1950-2009 period. They found that the companies whose planes crashed had greater losses than the other companies when the collisions were disclosed, and the losses increased with the degree of accident fatality.

Although Ho et al. (2013) consider this result consistent with the hypothesis of Kaplansky and Levy (2010), that the behavior of airline stock prices is due to negative sentiments (bad mood, fear, anxiety, etc.) evoked by accidents with fatal victims, they assigned the losses in the market value of the stocks to the losses expected as a result of accidents - reduced demand for travel, possible increases in premiums charged by insurance companies, damage to reputation and brand, loss of confidence from customers, and so on.

Capelle-Blancard and Laguna (2010) have studied the reactions of the capital market to explosions in the premises of 64 petrochemical industries in the period 1990-2005, which resulted in toxic releases, and at least one death or serious injury. They noted that there was an approximate $1.3 \%$ drop in the value of the stocks of 
these companies in the two days after the accidents; and that this fall was strongly associated with the severity of the accidents, expressed by the number of people affected and by the release of toxic substances; and the bad reputation of the companies, measured by the number of accidents previously experienced by them. Expanding the horizon of analysis, Capelle-Blancard and Laguna (2010) found that losses in the value of the stocks of companies whose accidents caused environmental damage were higher than the losses incurred by the other injured companies and that this difference increased over time.

Capelle-Blancard and Laguna (2010) have attributed the fall in the price of companies' stocks to the costs they have to incur to compensate the victims, to recover the environmental damage caused, to pay the fines normally levied by governments in these cases, and to renew the insurance they usually contract. They also mentioned that, after the accidents, the authorities usually review the regulations that govern the operation of the entire industrial segment, and this naturally increases the costs of all companies in the sector. Finally, they have emphasized that these companies have to invest in recovering their reputations.

Fersltl et al. (2012) have shown that the nuclear accident in Fukushima-Daiichi in March 2011 reduced the stock prices of nuclear power companies in the short term but increased the share price of alternative-energy companies in Japan, in France, and in Germany. In Japan, the price changes were followed by an increase in stock volatility. Fersltl et al. (2012) ascribed these effects to the uncertainties about the political implications of the accident in Japan, and to the expectations of the French and German markets that these countries would make changes in their energy matrix.

Katsikides et al. (2016) studied the reactions of the capital market to some events, among them the oil spills from the Macondo well in the Gulf of Mexico, in April 2010, explored by British Petroleum (BP) and from the Exxon supertanker Valdez, in March 1989, in Alaska. In both cases, there was a loss in the market value of the stocks of the companies involved, but the evolution of these losses was different. Considering the interval of 60 days after the events, the losses of BP's shares appeared soon, but were not significant, becoming so within a period of up to 45 days, and persisted with less significance within 60 days. Exxon's losses appeared as soon as the accident was reported, remained significant within 45 days, and became insignificant within 60 days. According to these authors, the differences in the evolution of the losses of these two accidents were compatible with the peculiarities of the two accidents.

The results of the present research demonstrate that the behavior of the returns of ADRs and Vale S.A. common stocks after the failures of the Mariana and Brumadinho dams reproduce patterns similar to those observed in previous studies, respecting the characteristics of the two accidents.

It is worth emphasizing that the studies about disasters previously reviewed were based on the analysis of the companies' returns and stock prices, and therefore have focused on the relevance of these episodes to the market. The present study also examines the behavior of the trading volumes of the ADRs and of the common stocks of Vale S.A. after the disclosure of the accidents to analyze the relevance of these events to investors.

As far as it could be observed, there are no studies that have analyzed investor reaction to accidents caused voluntarily or involuntarily by companies. Thus, this research will assume that investors reaction is motivated by loss aversion (Kahneman, 2011). Nevertheless, this is not enough to assume that they will try to get rid of the securities they possess as soon as they get to know about accidents. To determine their reactions, it is necessary to consider the perspective they adopt to evaluate their investments, whether narrow or broad.

According to Kahneman (2011, p. 340), investors who adopt the narrow perspective "build their preferences every time they face a risky choice" and, because they are averse to losses, will be particularly likely to avoid them. Therefore, they will probably feel encouraged to sell their securities as soon as accidents are reported. Conversely, sophisticated investors are aware of the risks they take when buying corporate securities and take steps to keep them at acceptable levels. Adopting a broad perspective when investing their resources, sophisticated investors face losses less emotionally and are willing to take risks in the expectation that they will be properly remunerated. They can even buy securities from companies that have been involved in accidents if they see an opportunity to make gains in the future.

Presuming that there are investors in the market with different perspectives, it can be hypothesized that coeteris paribus the trading volumes of securities will tend to increase whenever the companies that have issued them get involved in accidents or are affected by them even indirectly. Or arguing as Beaver (1968), the increase of the trading volume of the securities will result of the lack of consensus of the investors about the impact of the accidents on the prices of the securities. 


\section{Data and Methodology}

This research has used the case study approach (Yin, 2018) and the events' study methodology (MacKinlay, 1997; Campbell, Lo, \& MacKinlay, 1997; Kaplanski \& Levy, 2010; Ho, Qiu, \& Tang, 2013) to document and compare the capital market and investors reactions to the collapses of the Mariana and Brumadinho dams. In this vein, the returns and trading volumes of the common stocks of Vale S.A. in Brasil, Bolsa, Balcão (B3), and the returns and trading volumes of the American Depository Receipts (ADR) of this company on the New York Stock Exchange (NYSE) were analyzed in the eleven days following of the dates of the dams' collapses.

On November 5, 2015, B3 and NYSE were operating normally, thus, the Fundão dam failure date was considered the event date $\left(\mathrm{D}_{0}\right)$ for the reaction analysis. However, on the date of the failure of Dam 1 of the Córrego do Feijão mine, B3 was closed because it was a public holiday in São Paulo City. Therefore, two dates were considered for this event in the analyses. For B3, the event date $\left(\mathrm{D}_{0}\right)$ was January 28,2019 , the first trading date after the dam collapse; and for the NYSE, the event date $\left(\mathrm{D}_{0}\right)$ was January 25, 2019.

Given that event studies affecting specific companies are based on the analysis of the abnormal (or unexpected) returns of the stocks/ADRs and of the abnormal trading volumes of traded stocks/ADRs. The returns and trading volumes of the traded stocks/ADRs on the 120 days before the event dates were used to estimate market model parameters and average trading volumes for Vale's stocks and ADRs.

The operational definitions of the abnormal returns, the abnormal cumulative returns, and the abnormal volume of securities traded are formally described in Figure 1.

\begin{tabular}{|c|c|c|}
\hline & Trading volume of shares and ADR's & Returns on shares and ADR's \\
\hline 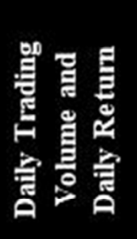 & $\begin{array}{l}\qquad \mathrm{V}_{\mathrm{it}}=\mathrm{Q}_{\mathrm{it}} / \mathrm{QC}_{\mathrm{it}} \\
\mathrm{V}_{\mathrm{it}}=\text { Percentage of the number of shares } \mathrm{i} \text { in circulation } \\
\text { traded on day } \mathrm{t} \text {. } \\
\mathrm{Q}_{\mathrm{it}}=\text { number of shares traded on day } \mathrm{t} \text {. } \\
\mathrm{QC}_{\mathrm{it}}=\text { number of shares traded } \mathrm{i} \text { in circulation on day } \mathrm{t} \text {. }\end{array}$ & $\begin{array}{l}\qquad \mathrm{R}_{\mathrm{it}}=\frac{\left(\mathrm{P}_{\mathrm{t}}-\mathrm{Pt}_{\mathrm{l}}\right)}{\mathrm{P}_{\mathrm{t}-1}} \\
\mathrm{R}_{\mathrm{t}} \text { is the rate of return on shares } \mathrm{i} \text { on day } \mathrm{t} \text {; } \\
\mathrm{P}_{\mathrm{t}} \text { is the adjusted closing price of shares } \mathrm{i} \text { on day } \mathrm{t} \text {; } \\
\mathrm{P}_{\mathrm{t}-1} \text { is the adjusted closing price of shares } \mathrm{i} \text { on day } \mathrm{t}-1 \text {. }\end{array}$ \\
\hline 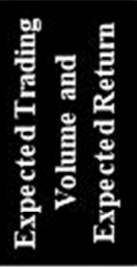 & $\begin{array}{l}\qquad E\left(V_{i}\right)=(1 / N) \sum V_{i t} \\
E\left(V_{i}\right)=\text { Expected percentage of the traded number of } \\
\text { shares } i \text { in circulation. } \\
N \text { is the number of non-missing trading volume over the } \\
\text { estimation interval. }\end{array}$ & $\begin{array}{l}\qquad E(R i t)=\alpha_{i}+\beta_{i} R_{m t} \\
E\left(R_{i j}\right) \text { is the expected return of share } i \text { on day t. } \\
R_{m t} \text { is the market return on day t. }\end{array}$ \\
\hline 飠 & $\begin{array}{l}\qquad \mathrm{AV}_{\mathrm{it}}=\mathrm{Vit}-\mathrm{E}(\mathrm{Vi}) \\
\mathrm{AV} \mathrm{V}_{\mathrm{it}}=\text { Abnormal volume, measured in terms of the } \\
\text { percentage of the amount of shares in circulation, of } \\
\text { share } \mathrm{i} \text { on dayt. }\end{array}$ & $\begin{array}{l}\qquad A R_{i t}=R i t-E(R i t) \\
A R_{i t} \text { is the abnormal or unexpected return of share } i \text { on } \\
\text { day t. }\end{array}$ \\
\hline 㟒党 & Not applicable. & $\begin{array}{l}\qquad \operatorname{CAR}_{\mathrm{it}}(0, \mathrm{n})=\sum_{\mathrm{t}=0}^{\mathrm{t}=\mathrm{n}} \mathrm{AR}_{\mathrm{it}} \\
\mathrm{CAR}_{\mathrm{it}} \text { is the abnormal cumulative return of share } \mathrm{i} \text { on } \\
\text { day t. } \mathrm{t} \text { varies from zero (event date) to } \mathrm{n} \text { (last day of the } \\
\text { event interval). }\end{array}$ \\
\hline
\end{tabular}

Note. (a) the stock market index used was the IBOVESPA in Brazil and the NYSE in the USA. (b) for the days without information on the traded price or volume, the information available on the previous day was repeated; (c) we decided not to exclude the outliers because the estimation interval is long enough. 
To assess the degree of significance of both the daily abnormal returns and the daily abnormal trading volume during the event window, we used the Student t-test as indicated in the following equation.

$$
\text { Test } t=\frac{\mathrm{x}_{\mathrm{it}}}{\sqrt{\frac{1}{N} \sum_{i=1}^{N} \widetilde{\sigma}_{i}^{2}}}
$$

Where,

$\mathrm{X}_{\mathrm{it}}$ is equal to $\mathrm{AR}_{\mathrm{it}}$, the abnormal return of security $\mathrm{i}$ on day $\mathrm{t}$, or $\mathrm{ATV}_{\mathrm{it}}$, the abnormal trading volume of security $\mathrm{i}$ on day $\mathrm{t}$.

$\sigma^{2}$ is the estimated variance of the abnormal return and the abnormal trading volume of security $i$ within the estimation interval.

$N$ is the number of observations in the estimation interval.

The trading volume of stocks, the adjusted common stock prices, the ADR prices, and the stock market indexes (Ibovespa and NYSE) were obtained from the Yahoo Finance website (www.finance.yahoo.com).

\section{Research Results}

Panel 1 of Table 2 shows the abnormal returns and the cumulative abnormal returns of Vale's common stocks and ADRs, and Panel 2 of this table shows the abnormal trading volumes of Vale's common stocks and ADRs in the eleven days following the occurrences of the collapses of the two dams. Figures 1 and 2 present the behavior of cumulative abnormal returns and abnormal trading volumes of Vale S.A. common shares and ADRs in these same periods.

In general, the results shows that extreme local environmental disasters associated with a cross-listed multinational company have the potential to impact both the trading volume and the stock prices not only in the local market but also in a foreign capital market. We also observed a reversal effect in the stock prices, as observed by Kaplanski and Levy (2010) and Katsikides, Markoulis and Papaminas (2016), but in a different span of time of the aviation disaster and the libor scandal. 
Table 2. Stock market and investor reaction around the announcements of the environmental disasters

\begin{tabular}{|c|c|c|c|c|c|c|c|c|c|c|c|c|}
\hline \multicolumn{13}{|c|}{ Panel 1 - Abnormal Return (AR) and Cumulative Abnormal Return (CAR) } \\
\hline & \multicolumn{6}{|c|}{ BRUMADINHO } & \multicolumn{6}{|c|}{ MARIANA } \\
\hline & \multicolumn{3}{|c|}{ VALE3 } & \multicolumn{3}{|c|}{ ADR VALE } & \multicolumn{3}{|c|}{ VALE3 } & \multicolumn{3}{|c|}{ ADR VALE } \\
\hline & $\underline{\mathrm{AR}}$ & & CAR & $\underline{\mathrm{AR}}$ & & $\underline{\mathrm{CAR}}$ & $\underline{\mathrm{AR}}$ & & $\underline{\mathrm{CAR}}$ & $\underline{\mathrm{AR}}$ & & $\underline{\mathrm{CAR}}$ \\
\hline $\mathrm{d} 0$ & holiday & & & $-9.4 \%$ & $* * *$ & & $-3.8 \%$ & & & $-3.2 \%$ & & \\
\hline$d+1$ & $-23.0 \%$ & $* * *$ & $-23.0 \%$ & $-17.5 \%$ & $* * *$ & $-26.9 \%$ & $-3.9 \%$ & & $-7.7 \%$ & $-4.7 \%$ & & $-8.0 \%$ \\
\hline$d+2$ & $0.8 \%$ & & $-22.2 \%$ & $2.0 \%$ & & $-24.8 \%$ & $0.9 \%$ & & $-6.8 \%$ & $0.2 \%$ & & $-7.8 \%$ \\
\hline$d+3$ & $8.1 \%$ & $* * *$ & $-14.1 \%$ & $8.0 \%$ & $* * *$ & $-16.9 \%$ & $-0.4 \%$ & & $-7.3 \%$ & $1.3 \%$ & & $-6.5 \%$ \\
\hline$d+4$ & $-2.6 \%$ & & $-16.7 \%$ & $-2.3 \%$ & & $-19.1 \%$ & $-3.5 \%$ & & $-10.8 \%$ & $-0.8 \%$ & & $-7.3 \%$ \\
\hline$d+5$ & $1.4 \%$ & & $-15.3 \%$ & $0.5 \%$ & & $-18.6 \%$ & $-1.3 \%$ & & $-12.1 \%$ & $1.1 \%$ & & $-6.2 \%$ \\
\hline$d+6$ & $-3.9 \%$ & ** & $-19.2 \%$ & $-4.1 \%$ & * & $-22.7 \%$ & $3.3 \%$ & & $-8.8 \%$ & $3.0 \%$ & & $-3.2 \%$ \\
\hline$d+7$ & $-0.1 \%$ & & $-19.3 \%$ & $-1.0 \%$ & & $-23.7 \%$ & $-3.3 \%$ & & $-12.1 \%$ & $-2.9 \%$ & & $-6.0 \%$ \\
\hline$d+8$ & $-2.1 \%$ & & $-21.4 \%$ & $-6.0 \%$ & $* * *$ & $-29.8 \%$ & $-5.0 \%$ & $*$ & $-17.1 \%$ & $-5.0 \%$ & & $-11.1 \%$ \\
\hline$d+9$ & $-1.9 \%$ & & $-23.2 \%$ & $-0.7 \%$ & & $-30.4 \%$ & $-0.3 \%$ & & $-17.4 \%$ & $0.6 \%$ & & $-10.5 \%$ \\
\hline$d+10$ & $3.1 \%$ & & $-20.1 \%$ & $1.8 \%$ & & $-28.6 \%$ & $-2.1 \%$ & & $-19.5 \%$ & $-0.1 \%$ & & $-10.6 \%$ \\
\hline \multicolumn{13}{|c|}{ Panel 2 - Abnormal Trading Volume (ATV) } \\
\hline & \multicolumn{6}{|c|}{ BRUMADINHO } & \multicolumn{6}{|c|}{ MARIANA } \\
\hline & VALE3 & & & ADR & & & $\underline{\text { VALE3 }}$ & & & ADR VA & & \\
\hline & & & & $\overline{\text { VALE }}$ & & & & & & & & \\
\hline & $\underline{\mathrm{ATV}}$ & & & $\underline{\mathrm{ATV}}$ & & & $\underline{\mathrm{ATV}}$ & & & $\underline{\mathrm{ATV}}$ & & \\
\hline $\mathrm{d} 0$ & holiday & & & $11.80 \%$ & * & & $-0.17 \%$ & * & & $-0.33 \%$ & * & \\
\hline$d+1$ & $7.89 \%$ & * & & $11.17 \%$ & * & & $0.84 \%$ & * & & $4.43 \%$ & * & \\
\hline$d+2$ & $2.39 \%$ & * & & $5.44 \%$ & $*$ & & $-0.87 \%$ & * & & $-0.45 \%$ & * & \\
\hline$d+3$ & $2.37 \%$ & * & & $6.54 \%$ & * & & $-0.46 \%$ & * & & $0.11 \%$ & & \\
\hline$d+4$ & $1.03 \%$ & $*$ & & $1.99 \%$ & $*$ & & $-0.63 \%$ & $*$ & & $-0.27 \%$ & * & \\
\hline$d+5$ & $0.14 \%$ & * & & $0.53 \%$ & $*$ & & $-0.23 \%$ & $*$ & & $-0.76 \%$ & * & \\
\hline$d+6$ & $0.84 \%$ & $*$ & & $3.31 \%$ & $*$ & & $-0.67 \%$ & $*$ & & $-1.59 \%$ & * & \\
\hline$d+7$ & $0.18 \%$ & $*$ & & $0.69 \%$ & $*$ & & $-0.40 \%$ & $*$ & & $-0.84 \%$ & * & \\
\hline$d+8$ & $0.52 \%$ & $*$ & & $4.00 \%$ & $*$ & & $-0.48 \%$ & $*$ & & $-0.38 \%$ & * & \\
\hline$d+9$ & $0.63 \%$ & $*$ & & $2.87 \%$ & $*$ & & $-0.12 \%$ & $* *$ & & $-0.81 \%$ & * & \\
\hline $\mathrm{d}+10$ & $1.43 \%$ & * & & $3.92 \%$ & * & & $-0.61 \%$ & $*$ & & $-1.67 \%$ & * & \\
\hline
\end{tabular}

Note. (a) AR - Abnormal Return; CAR - Cumulative Abnormal Return; ATV - Abnormal Trading Volume, (b) The securities analyzed were: (1) In Brazil: VALE3 (common stocks) and Ibovespa Index and (2) In the United States: ADR VALE and NYSE NYA index, available at yahoofinance.com. (c) The Brumadinho (BRU) disaster occurred on January 25, 2019, around 3:00 p.m. in Brasilia-Brazil time, which corresponds to the Event Date $\left(\mathrm{D}_{0}\right)$. This day was a public holiday in São Paulo, so the first effective day of stock trading with the information was January 28, 2019, for the Brazilian market. Mariana's disaster occurred on November 5, 2015, around 3:30 pm. in Brasilia-Brazil time, which corresponds to the Event Date $\left(\mathrm{D}_{0}\right)$. (d) t-test: * for $10 \%$ significance, $* *$ for $5 \%$ significance, and $* * *$ for $1 \%$ significance.

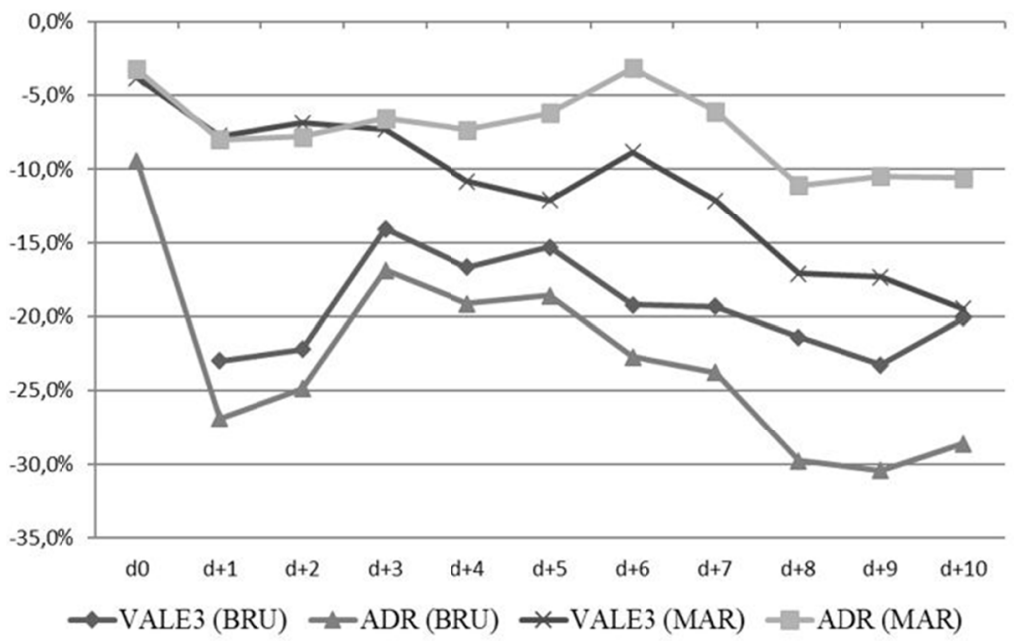

Figure 1. Cumulative abnormal return

Note. (a) The securities analyzed were: (1) VALE3 (common stocks) in Brazil and (2) ADR VALE in the United States. (b) The Brumadinho (BRU) disaster occurred on January 25, 2019, around 3:00 p.m. in Brasilia-Brazil time. This day was a public holiday in São Paulo, so the first effective day of stock trading with the information was January 28, 2019, for the Brazilian market. Mariana's (MAR) disaster occurred on November 5, 2015, around 3:30 pm. in Brasilia-Brazil time. 


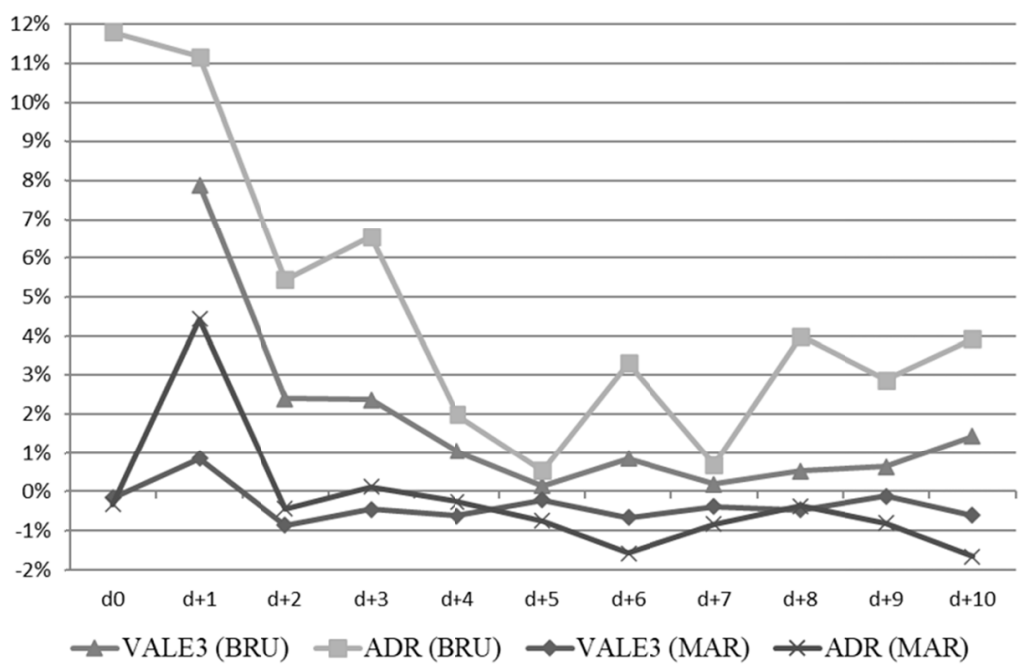

Figure 2. Abnormal trading volume

Note. (a) The securities analyzed were: (1) VALE3 (common stocks) in Brazil and (2) ADR VALE in the United States. (b) The Brumadinho (BRU) disaster occurred on January 25, 2019, around 3:00 p.m. in Brasilia-Brazil time. This day was a public holiday in São Paulo, so the first effective day of stock trading with the information was January 28, 2019, for the Brazilian market. Mariana's (MAR) disaster occurred on November 5, 2015, around 3:30 pm. in Brasilia-Brazil time.

\subsection{The Collapse of the Fundão Dam in Mariana}

Panel 1 of Table 2 and Figure 1 indicate that, after the Fundão dam collapsed, the abnormal returns of common shares and ADRs were mostly negative and considering the behavior patterns of these returns in the range of estimation, except for one case, they were not statistically significant. However, at the end of the eleven-day interval counted from the accident date, the magnitude of the cumulative abnormal returns was relevant: - $19.5 \%$ for common stocks and $-10.6 \%$ for ADRs. Therefore, we can conclude that the market reacted as was expected in this type of accident.

The information shown in Panel 2 of Table 2 and Figure 2 demonstrates that on the eleven days following the date of the accident, the abnormal trading volumes of the securities were mostly negative, being all statistically significant, but the investor reactions in B3 and NYSE were different. On the day after the accident $\left(\mathrm{D}_{+1}\right)$, the trading volume of ADRs on the NYSE was $4.43 \%$ higher than the average volume calculated on the 120 days of the estimation interval, and the trading volume of common stocks on B3 on that day was only $0.84 \%$ higher than expected. On the remaining days of the analysis interval, the abnormal trading volumes of the ADRs reached two other extremes, both negative. On the first day, $\left(\mathrm{D}_{+6}\right)$, the trading volume of the ADRs was below the average of $1.59 \%$, and on the second, $\left(\mathrm{D}_{+10}\right)$, it was below the average of $1.67 \%$. On the same days, the trading volumes of the common stocks were below the average, respectively, $0.67 \%$ and $0.61 \%$.

If the importance of an event for investors is characterized by a higher-than-expected trading volume of the securities, we can assume that the collapse of Fundão dam was considered only reasonably relevant by the NYSE ADR investors.

These results seem compatible with Vale's involvement with the accident. The Fundão dam belongs to Samarco, whose capital is shared equally between Vale and BHP Billiton. According to the 2015 Form 20F, Vale used this dam to dump the iron ore tailings produced at the Alegria Mine, which it operates, and without this option, the mine was forced to reduce its production. Furthermore, due to the accident, Vale also had to discontinue the sale of the run-of-mine ore that the Fazendão mine used to make to Samarco.

In addition, there is also the company's natural involvement in legal proceedings that follow events of this nature, and the fines and indemnities that certainly will have to be paid to governments and all those affected by the accident. For example, in November 2015, the Brazilian federal government and other state authorities collectively filed a public civil action against Samarco, Vale and BHPB Brasil Ltda., a Brazilian subsidiary of BHP Billiton plc ("BHP Billiton"). The Company informed that the plaintiffs claimed approximately R $\$ 20.2$ billion (US\$5.2 billion) in monetary damages and also a number of measures to remediate the environmental damages caused by the Fundão dam failure. Besides, in March 2016, these companies entered into a settlement 
agreement with the federal Attorney General of Brazil to develop and implement environmental and socio-economic programs to remediate and provide compensations, where remediation is not feasible, for damage caused by the dam failure. The Settlement Agreement has a term of 15 years, renewable for successive one-year periods until all the obligations under the Settlement Agreement have been met, with contributions of $\mathrm{R} \$ 2$ billion in 2016, $\mathrm{R} \$ 1.2$ billion in 2017, $\mathrm{R} \$ 1.2$ billion in 2018, and an annual minimum amount of $\mathrm{R} \$ 800$ million and an annual maximum amount of R \$1,600 million from 2019 to 2021 (see page 136 of the 2015 Form 20F).

Apparently, the evaluation of Murilo Ferreira, the then-president of Vale, led him to believe that the company could be kept out of the problem. According to Ragazzi and Rocha (2019), he only spoke publicly about the accident a week after it occurred, and on that occasion, he has made it clear that Samarco was an independent company, but that Vale would not exempt itself from its responsibilities.

\subsection{The Collapse of the Córrego do Feijão Mine in Brumadinho}

Panel 1 of Table 2 and Figure 1 reveal that, after the collapse of Dam 1 of Córrego do Feijão, the abnormal returns of the Vale's common stocks and ADRs have undergone a relevant and statistically significant decrease. On January 25, the abnormal return on ADRs was $-9.4 \%$. On January 28, the abnormal return on ADRs was $-17.5 \%$, and since it was the first day of trading at B3 after the accident, the abnormal return on common stocks was $-23 \%$. At the end of the 11 days of the analysis interval, the cumulative abnormal returns of the ADRs reached $-28.6 \%$, and of the common stocks, $-20.1 \%$.

Panel 2 of Table 2 and Figure 2 show that in the interval of eleven days from the date of the accident, the abnormal trading volumes of the securities were all positive and statistically significant, but the reactions of NYSE investors were much more intense than those of B3 investors. On January 25, the abnormal volume of traded ADRs was $11.8 \%$ of the ADRs in circulation. On January 28 , the abnormal volume of traded ADRs was $11.17 \%$, and as it was the first day of trading at B3 after the accident, the abnormal volume of traded common stocks was only $7.89 \%$. In ten of the eleven days after the dam had collapsed, when B3 and NYSE were trading, the abnormal trading volumes of ADRs traded on the NYSE were higher than the abnormal trading volumes of common stocks on B3.

Comparing the market and investors reactions to the collapses of the Fundão and Córrego do Feijão dams, it is clear that they reproduce the choreography of the reactions to various accidents that have already been studied by other authors and were proportional to the severity of the consequences and the degree of Vale's involvement in the accidents. The behavior of abnormal cumulative returns and abnormal trading volumes of Vale's securities in the two accidents suggests that the market and investors correctly realized that, in the case of Mariana, the expected losses, albeit significant, would be shared with Samarco and BHP, but in the case of Brumadinho, Vale would have to take on the expected losses alone.

To assess the effects of the collapse of Dam 1 at Vale S.A., some information extracted from the 20F 2019 form of this company is reproduced in Figure 3 (Vale, pp. 7-11).

The substantial drop in the returns of common stocks in B3 and of ADRs in NYSE on the eleven days following the collapse of Dam 1 of the Córrego do Feijão enables us to say that the market efficiently priced the impacts that the dam rupture has had and will still have on the company; and the increase in the trading volumes of the ADRs shows that ADR investors, more than investors of common stocks, considered the accident relevant. 


\section{“(i) Impacts on our financial performance and results of operations}

The main impacts in our income statement for the year ended December 31, 2019 was (i) US\$7.402 billion, including expenses and provisions to meet our obligations in connection with the decharacterization of our upstream dams and the obligations we assumed in preliminary settlement agreements, and (ii) a loss of US\$235 million in the "impairment and disposal of non-current assets" attributable to the write-off of the Corrégo do Feijão mine and other upstream dams.

\section{(ii) Liabilities and legal proceedings}

As of December 31, 2019, we recognized provisions in the total amount of US\$3.925 billion related to preliminary settlement agreements with authorities for compensation to affected persons and communities, donations and projects to restore the environment, including (i) US\$2.735 billion in connection with social and economic compensation and (ii) US\$1.190 billion in connection with environmental restoration and compensation. Our potential liabilities resulting from the dam rupture are significant, and additional provisions might be expected.

\section{(iii) Suspension of operations}

Following the dam rupture, we have suspended various operations, either voluntarily or as a result of revocation of licenses or court orders. The suspension of operations in its most critical level totaled 92.8 million metric tons per year of production capacity, but part of these operations resumed during 2019. Additional operations may be suspended as a result of new laws and regulations relating to the use of dams, or our inability to obtain the required licenses or the stability reports required by applicable regulations, as discussed below.

\section{(iv) New regulations}

Various governmental authorities have approved or proposed new regulations relating to licensing, use and operations of dams in response to the Dam I rupture. Additional rules imposing restrictions on mining operations and ancillary activities are expected. Also, new taxes, contributions or other obligations may be imposed on us as a result of the rupture of Dam I or its direct or indirect impacts. These rules may affect not only our iron ore operations, but also our base metals operations in Brazil and other operations that rely on dams.

\section{(v) Impact on reserves}

Our reported reserves have been affected by the ongoing investigations and legal proceedings involving the use of dams in our mining operations and by the new rules relating to licensing, use and operations of dams, which were adopted in response to the Dam I rupture.

\section{(vi) Uncertainties arising from increased safety requirements and external expert certification}

We are required to obtain a certification of stability (Stability Condition Statement, or "DCE"), which is provided by external experts following an audit, for most of our dams in Brazil in six-month intervals by March 31 and September 30 of each year, and for some, on an annual basis. Brazilian state and federal authorities are strengthening regulations on dam safety. External experts may be unwilling to provide these reports and certificates as a result of the uncertainties regarding the causes of the Dam I rupture, the increasing risk of liability, and uncertainties concerning the interpretation of new regulations. If any of our dams is unable to comply with safety requirements, we may need to suspend related operations, evacuate the area surrounding the dam, relocate communities and take other emergency actions."

Figure 3. The impacts of the Fundão dam rupture on Vale operations and results 


\subsection{Reflecting on Causal Attributions}

Researchers who have analyzed capital market reactions to different accidents have always made causal attributions. This section assesses the plausibility of two causes proposed in previous research for market and investor reactions to the collapses of Mariana and Brumadinho dams. The first is that the reactions of the markets can be explained by the sentiments of investors; and the second is that market reactions result from expectations that companies will directly or indirectly incur significant costs as a result of accidents.

Kaplanski and Levy (2010) assumed that the reaction of the US capital market to aviation accidents was explained by the fear, anxiety, and mood swings induced by the wide emotional media disclosure of these accidents.

Although this is a possibility, it is necessary to emphasize that Kaplanski and Levy (2010) did not measure investors' fear, anxiety, or mood swings, and therefore have not directly tested whether market reactions could be explained by these feelings. Furthermore, we must recognize that there are arguments and results that contradict the conclusions of these authors.

Major accidents always draw media attention and are reported with a heightened tone of emotion. Obviously, no one remains indifferent to the information disclosed about environmental damage, the number of deaths, injuries, homeless people, etc. However, we may assume that fear, anxiety, and mood swings are sentiments that normally affect survivors who have been directly or indirectly harmed by accidents, and those who remain exposed to the risks derived or evoked by accidents. Ragazzi and Rocha (2019) and Espíndola and Guimarães (2019) fully report the difficulties and fears faced by residents in the Brumadinho region and by residents in the vicinity of the other dams distributed across the State of Minas Gerais after the rupture of Dam 1 of the Córrego do Feijão. However, these are not the feelings that usually drive investors' decisions.

Investors invest their resources hoping to obtain the highest expected return possible for the risks they are taking. Therefore, they are particularly susceptible to associative activation (priming) for money. Based on empirical evidence, Khaneman (2011) states that money stimulates initiative and individualism, not a concern for others. This, nevertheless, does not mean that investors are immune to irrationality. It only suggests that there is a high probability that they will respond to accidents based on the financial and economic results they expect.

The precedence of selfish financial and economic results in the analysis of investor decisions is clearly highlighted in the proposition that Friedman and Friedman (1980, p. 5) attribute to Adam Smith: "If an exchange between two parties is voluntary, it will not take place unless both believe they will benefit from it". This proposition leads us to believe that the efficient operation of markets dispenses with the prior existence of high standards of conduct or the nobility of sentiments. As long as there are two interested parties, deals that benefit both will be closed, regardless of the object negotiated. The concern about this condition encouraged Sandel (2013) to gather several cases to propose that there are moral limits for the markets. In his opinion, there are problems that, in principle, should not be solved through the rules of the market. This is also the opinion of Ariely (2008), who believes that it is not advisable to apply the rules of the market in situations where social norms should rule.

The results of Jones and Rubin's (2001) research support the hypothesis that capital markets are driven by more mundane and pragmatic sentiments than those suggested by Kaplanski and Levy (2010). They have shown that accidents with energy and oil companies that did not compromise the quality of their products and services, nor their reputations with suppliers and employees, had no significant negative impact on the companies' market value, despite having affected their social reputations. Capelle-Blancard and Laguna (2010), and Ho et al. (2013) expressed this same belief when they assumed that losses in the market value of the stocks of companies involved in accidents were due to the expectation of losses that certainly occur in these events. These losses reduce companies' assets, profits, and cash flows, and, consequently, may affect the market value of their stocks.

This seems to be the case for the reaction of the market and Vale S.A. investors to the collapse of the Fundão dam in Mariana. There was a reduction in abnormal returns on common stocks and ADRs, probably due to the expected impacts of penalties and indemnities that Vale would have to bear as a Samarco shareholder on its future cash flows. Yet, the behavior of the abnormal trading volumes of the securities indicated that investors did not regard the accident as relevant perhaps because they did not expect it to significantly affect Vale's ability to comply with its contractual commitments.

Comparing the collapses of the Mariana and Brumadinho dams, the biggest expected losses for Vale S.A. were related to the Brumadinho dam. Vale S.A.'s management disclosed in the $201920 \mathrm{~F}$ form the losses that could be recognized until the end of the year but were zealous to mention that there were losses that could only be 
determined as the accident consequences unfolded. This may be the reason for the significant reduction in abnormal returns on common stocks and ADRs after the accident.

The increases in abnormal trading volumes of common stocks and of ADRs after the Brumadinho dam collapse possibly resulted from the decisions of investors who adopted different perspectives to analyze their investments in Vale, as predicted by Khaneman (2011). Some, with a narrow perspective, sold their securities motivated by loss aversion, and others, with a broader perspective, anticipating that the company would be able to recover, bought Vale's securities taking advantage of the drop in its prices.

Capelle-Blancard and Laguna (2010) and Fersltl et al. (2012) mentioned that some accidents have repercussions that go beyond the limits of the involved companies and affect all the companies in an economic sector or, eventually, all companies, no matter what they do or where they are. In these cases, the managers of the companies affected are forced to incur contracting costs in political processes (Watts and Zimmerman, 1990: 135) to defend their companies' interests and to prevent interventions that may limit their choices and impose ways of acting that they deem counterproductive.

We must remember that the political disputes that normally result from severe accidents which caused great repercussions are complex, have high contracting costs and do not always favor companies. Therefore, in addition to contracting costs, companies incur costs to implement the changes imposed on them, and, depending on how the political process evolves, more costs are incurred to recover their reputations. All of this certainly affects the companies' expected cash flows and, as a consequence, can stimulate market and investor reactions.

To illustrate the contracting costs in political processes that have resulted from the collapse of the Fundão dam, it is worth mentioning that, in 2016, Samarco, Vale, and BHP Billiton signed the Transaction and Conduct Adjustment Term and created the Renova Foundation. The Foundation's website (https://www.fundacaorenova.org/en/about-the-agreement/) "explains that this Term is an innovative option to the conventional judicial conflict resolution model and defines the scope of the Renova Foundation's activities. Forty-two programs and projects are being implemented (in the long term) in the impacted area of the Doce River and tributaries. An agreement signed by dozens of entities, including Federation bodies, such as IBAMA, ICMBio, ANA, state and municipal bodies, Samarco, Vale and BHP, representatives of the basin committee, established guidelines on how the process would be developed" (Renova Foundation, 2017).

Despite the bold tone of the text on that website, Marshall (2018) comments that the process that led to the signing of the Transaction and Conduct Adjustment Term and the creation of the Renova Foundation did not meet the expectations of all parties involved in the accident, especially those who were victimized, suggesting that the managers of Samarco, Vale, and Billiton acted vigorously to limit the accident impact and preserve their companies' autonomy.

The collapse of the tailings dam at the Córrego do Feijão mine had consequences that were not limited to Vale S.A. Two of them were explicitly pointed out in the $201920 \mathrm{~F}$ report: the prohibition of the construction of dams by the upstream raising method, and the increase in the cost to obtain the Stability Condition Declarations for the licensing of dams.

Among the dam construction methods, the one with the lowest cost, but the least safe, is upstream raising (Ragazzi \& Rocha, 2019). The Fundão dam and Dam 1 of Córrego do Feijão were built using this method.

After the Fundão dam collapse, there was an unsuccessful attempt to pass a standard norm preventing the use of the upstream raising method for the construction of dams (Espíndola \& Guimarães, 2019). However, the social and political pressures resulting from the rupture of Dam 1 of the Córrego do Feijão led the National Mining Agency, a successor to the National Department of Mineral Production, to publish Resolution No. 4 in February 2019 prohibiting the use of the upstream method in the entire national territory and establishing that all dams of this type be decommissioned by the end of 2023 .

The increase in costs expected to obtain the Stability Condition Declarations of the dams was a natural consequence of the speed with which the government intervened in the company responsible for issuing the Declarations for the Córrego do Feijão dam, and in the identification and arrest of the technicians who signed them. The $201920 \mathrm{~F}$ report explicitly expresses the concerns of Vale's management regarding this issue.

In conclusion, the reactions of the market and of the investors to the collapses of the two dams appear to have been proportional to the characteristics of these accidents and motivated by the expectation that they would bring economic and financial losses to Samarco and its investors, and Vale. Among the losses, the contracting costs in the political processes that resulted from the accidents stand out. If well conducted, these processes preserve the companies' autonomy and limit losses. However, the chances of success do not depend on managers' 
competence alone. Accidents such as the collapse of mining tailings dams, due to the effects they have on the affected populations, the environment, the economies of the affected localities, states and country, and international relations, mobilize society and various stakeholders, with consequences that are not entirely predictable.

\section{Conclusions and Final Remarks}

This research has used the event study method to analyze the market reaction, reflected in the unexpected returns of common stocks and ADRs, and of investor reaction reflected in the unexpected volumes of common stocks and ADRs of Vale S.A. in the eleven days following the disruptions of the Fundão dams in Mariana and Córrego do Feijão in Brumadinho.

Regarding the Fundão dam failure, we observed that, at the end of the eleven days, there was a significant reduction in the abnormal returns of the common stocks and ADRs, although the daily abnormal returns were not statistically significant, denoting that the market efficiently estimated the losses and difficulties that Vale would face as a result of the accident. However, the abnormal volumes of common stocks and ADRs traded within eleven days from the date of the accident were mostly negative and all statistically significant, but the reactions of B3 and NYSE investors were different. These reactions indicate that investors quickly reached a consensus on the consequences of the accident.

The situation of the collapse of Dam 1 of the Córrego do Feijão in Brumadinho was different. It belongs only to Vale S.A., the accident was technically similar to the collapse of the Fundão dam that occurred in the same state less than four years earlier, and caused the death of 270 people. In this case, in the eleven days following the accident, the daily abnormal returns of common shares and ADRs suffered a relevant and statistically significant drop, and at the end of this period, the losses were relevant. Once again the market, the market efficiently estimated the losses and difficulties that Vale would suffer.

In the case of Dam 1 of the Córrego do Feijão, unlike what happened in the Fundão dam failure, the abnormal trading volumes of the securities were all positive and statistically significant, but the reactions of NYSE investors were much more intense than those of B3 investors. This suggests that investors found it difficult to reach a consensus on the magnitude of the losses, and this difficulty was higher for those who were operating on the NYSE.

Notwithstanding, the causes attributed by Kaplanski and Levy (2010) for the losses that occurred in the market after major accidents have won hearts and minds around the world, it can be argued that the reactions of the market and the investors to the collapse of the Fundão and Córrego do Feijão dams were probably guided by the expectation that the companies involved would incur losses and by the difficulty of reaching a consensus on the size of these losses. These losses include the costs of contracting in the political process that would certainly take place after the accidents.

The differences in the reactions observed in B3 and NYSE probably resulted from differences in the perceptions of participants in these markets which are built based on their familiarity with the legal framework and with the idiosyncrasies of the Brazilian political process.

The study of the cases of tailings dam failures teaches that mining companies generate large externalities. With the opening of the mines come the positive externalities. The initial investments change the economy and the society in the areas where the deposits are located. In addition to the mining companies' units, service providers that are part of the mining supply chain also come to the region. Among them are supermarkets, pharmacies, department stores, suitably equipped hospitals, schools of various types, gym academies, restaurants, hotels, etc. Although these facilities are meant to serve the mining workers and their families, they naturally benefit, directly and indirectly, the local population who becomes obviously delighted with the arrival of modern services in regions that are generally far from large centers.

However, when the mines come into operation and gain scale, the negative externalities begin to emerge. Truck traffic intensifies, the flow of people with different habits from local standards increases bringing unexpected consequences to the inhabitants of the region, the quality of the public services erodes, the local society begins to suffer interferences from the mine's administration, and there is an increase in all kinds of pollution, the landscape begins to change, etc. Besides, there are the risks associated with the exploitation of the deposits unknown to the citizens, despite the best efforts made by the mining companies' managers to disclose them. Over time, locals realize that modern times comes at a price, and relations between them and the managers of mining companies become harsher and ambiguous. Neither party wants to break off the relationship although the differences of interest seem irreconcilable. 
In view of the recurring accidents with similar characteristics, we can say that there are no profits that justify the option to build unsafe dams, and for neglecting the maintenance and safety of these installations. No compensation can restore lost lives, broken families, and irreparable damage to nature caused by avoidable accidents. Ideally, managers of mining companies should commit to applying safe exploration methods that preserve people's health and nature.

Accidents in tailings dams may eventually occur even when the dams are built with safe methods, are properly preserved, and use adequate safety equipment kept in perfect working order. Based on what is known about how the market and investors react to accidents in general, conscious managers interested in preserving the company and investors' assets should communicate clearly and promptly to the market the extent of the problems that occurred, the costs expected as a result of the disasters, as well as the problems that they expect to face to maintain contractual commitments with suppliers, employees, and customers. However, this is easier said than done. An impediment to adopting an open and totally transparent communication strategy is the contracting costs in the political processes that always result from major accidents. In this case, managers are usually inspired by the principle of non-self-incrimination provided for in the Federal Constitution of 1988 (no one is obliged to self-incriminate or present evidence) to decide what and how to report, accepting the consequences that unanswered questions will have for themselves, their companies and all other stakeholders.

\section{References}

Ariely, D. (2008). Previsivelmente irracional: as forças ocultas que formam as nossas decisões. Rio de Janeiro, BR: Elsevier.

Baker, M., \& Wurgler, J. (2006). Investor Sentiment in the Stock Market. Journal of Economic Perspectives, 21(2), 129-151. https://doi.org/10.1257/jep.21.2.129

Bamber, L. S., Barron, O. E., \& Stober, T. L. (1999). Differential Interpretations and Trading Volume. The Journal of Financial and Quantitative Analysis, 34(3), 369-386. https://doi.org/10.2307/2676264

Bamber, L. S., \& Cheon, Y. S. (1995). Differential Price and Volume Reactions to Accounting Earnings Announcements. The Accounting Review, 70(3), 417-441. https://doi.org/10.2307/2676264

Barron, O. E. (1995). Trading volume and belief revisions that differ among individual analysts. The Accounting Review, 70(4), 581-597. https://www.jstor.org/stable/248248

Beaver, W. H. (1968). Information content of annual earnings announcements. Journal of Accounting Research, 6, 67-92. https://doi.org/10.2307/2490070

Brasil. (2016). Constituição da República Federativa do Brasil [texto constitucional promulgado em 5 de outubro de 1988...]. Brasília: Senado Federal, Coordenação de Edições Técnicas. Retrieved from https://www2.senado.leg.br/bdsf/bitstream/handle/id/518231/CF88_Livro_EC91_2016.pdf

Campbell, J. Y., Lo, A. W., \& MacKinlay, C. (1997). The econometrics of financial markets. Princeton University Press, New Jersey. https://doi.org/10.1515/9781400830213

Capelle-Blancard, G., \& Laguna, M. (2010). How does the stock market respond to chemical disasters? Journal of Environmental Economics and Management, 59(2), 192-205. https://doi.org/10.1016/j.jeem.2009.11.002

Davies, M., \& Martin, T. (2009). Mining Market Cycles and Tailings Dams Incidents. 13th International Conference on Tailings and Mine Waste, November 1-4, Banff, Alberta, Canada. https://docplayer.net/14797608-Mining-market-cycles-and-tailings-dam-incidents.html

Espindola, H. S., \& Guimarâes, D. J. M. (2019). História Ambiental dos Desastres: uma agenda necessária [Debate]. Revista Tempo e Argumento, 11(26), 560-573. https://doi.org/10.5965/2175180311262019560

Ferstl, R., Utz, S., \& Wimmer, M. (2012). The Effect of the Japan 2011 Disaster on Nuclear and Alternative Energy Stocks Worldwide: An Event Study. Business Research, 5(1), 25-41. https://doi.org/10.1007/BF03342730

Friedman, M., \& Friedman, R. D. (1980). Free to choose: A personal statement. New York, NY: Harcourt Brace Jovanovich.

Fundação Renova. (2017). Relato de Atividades 2016. Belo Horizonte, MG: Fundação Renova.

Ho, J. C., Qiu, M., \& Tang, X. (2013). Do airlines always suffer from crashes? Economic Letters, 118, 113-117. https://doi.org/10.1016/j.econlet.2012.09.031

Jones, K., \& Rubin, P. H. (2001). Effects of harmful environmental events on reputations of firms. Advances in 
Financial Economics, 6, 161-182. https://doi.org/10.1016/S1569-3732(01)06007-8

Kahneman, D. (2011). Thinking, Fast and Slow. New York, NY: Farrar, Straus and Giroux.

Kaplanski, G., \& Levy, H. (2010). Sentiment and stock prices: The case of aviation disasters. Journal of Financial Economics, 95, 174-201. https://doi.org/10.1016/j.jfineco.2009.10.002

Katsikides, S., Markoulis, S., \& Papaminas, M. (2016). Corporate Social Responsibility and Stock Market Performance: An Event Study Approach. International Journal of Engineering and Advanced Technology, 6(2), 1-8.

MacKinlay, A. C. (1997). Event Studies in Economics and Finance. Journal of Economic Literature, 35(1), 13-39. Retrieved from https://www.jstor.org/stable/2729691

Marshall, J. (2018). Tailings dam spills at Mount Polley and Mariana: Chronicles of Disasters Foretold. In Canadian Centre for Policy Alternatives (pp. 1-64). Retrieved from https://www.policyalternatives.ca/tailings-disasters

Massaro, M., Dal Mas, F., Chiappetta Jabbour, C. J., \& Bagnoli, C. (2020). Crypto-economy and new sustainable business models: Reflections and projections using a case study analysis. Corporate Social Responsibility and Environmental, 27, 2150-2160. https://doi.org/10.1002/csr.1954

Mintzberg, H. (1982). A Note on that Dirty Word "Efficiency". Interfaces, 12(5), 101-105. https://doi.org/10.1287/inte.12.5.101

Ragazzi, L., \& Rocha, M. (2019). Brumadinho: a engenharia de um crime. Belo Horizonte, MG: Editora Letramento.

Sánchez, L. E., Alger, K., Alonso, L., Barbosa, F. A. R., Brito, M. C. W., Laureano, F. V., ... Kakabadse, Y. (2018). Impacts of the Fundão Dam failure: A pathway to sustainable and resilient mitigation [Rio Doce Panel Thematic Report / Monographic Series no 1]. Gland, Switerzland: UICN. https://doi.org/10.2305/IUCN.CH.2018.18.en

Sandel, M. J. (2013). O que o dinheiro não compra: os limites morais do mercado (5 ed.). Rio de Janeiro, RJ: Civilização Brasileira.

Simeoni, L., Tosatti, G., Luca, G., \& Longo, M. (2017). The Stava catastrophic failure of July 19, 1985 (Italy): technical-scientific data and socioeconomic aspects. CSE Journal - City Safety Energy, 1, 17-30. https://doi.org/10.12896/cse201700100111

Vale. $\quad$ (2019). Form $2019 . F \quad$ Retrieved from $\mathrm{http}: / / \mathrm{www} . v a l e . c o m / b r a s i l / p t / i n v e s t o r s /$ information-market/annual-reports/20f/paginas/default.aspx

Wang, M., Qiu, C., \& Kong, D. (2011). Corporate Social Responsibility, Investor Behaviors, and Stock Market Returns: Evidence from a Natural Experiment in China. Journal of Business Ethics, 101(1), 127-141. https://doi.org/10.1007/s10551-010-0713-9

Watts, R. L., \& Zimmerman, J. L. (1990). Positive Accounting Theory: A Ten-Year Perspective. The Accounting Review, 66(1), 131-156. http://arikamayanti.lecture.ub.ac.id/files/2014/03/PAT-a-ten-year-perspective.pdf

Yin, R. K. (2018). Case Study Research and Applications: Design and Methods (6th ed.). Thousand Oaks, United States: SAGE Publications Inc.

\section{Notes}

Note 1. The Renova Foundation is an autonomous and non-profit entity, responsible for remediating the impacts caused by the collapse of the Fundão dam in Mariana (MG), and it was created following a legal commitment called Transaction and Conduct Adjustment Term, signed on March 2, 2016, by between Samarco Mineração, with the support of its shareholders, Vale and BHP Billiton, and the Federal Government, State Governments of Minas Gerais and Espírito Santo (two Brazilian states), and other government agencies.

\section{Copyrights}

Copyright for this article is retained by the author, with first publication rights granted to the journal.

This is an open-access article distributed under the terms and conditions of the Creative Commons Attribution license (http://creativecommons.org/licenses/by/4.0/). 